\title{
The Imagological Approach to Lithuanian and Latvian Contemporary Émigré Narratives ${ }^{1}$
}

\author{
LAURA LAURUŠAITE்
}

\begin{abstract}
A newly deployed identity, separated from its natural location, loses its solid national or ethnic status and hybridizes, acquiring features of the new context. Employing the concepts of self-image, imageme and counter-image introduced by contemporary literary imagology (Joep Leerssen), the article focuses on the $21^{\text {st }}$ century Lithuanian and Latvian émigré prose to provide an overview of a dislocated tradition and images that encode the continuity or transformation of the national identity. The aim of the discussion is to raise the issue of the specifics of the Baltic ethnic and national identity in the changing mobile world. The focus of the analysis is not on the social, but exceptionally on literary images, which are classified into topical image groups: ethnic images, Eastern European projections and exoticism as an extension of domestic identity.

Literary representations bear witness to the atrophy of ethnic and national consciousness, shifting expression of Baltic images, and their creative employment in the new contexts. Applied to the norms and standards of the new (e) migrant society, traditional ethnic and national imagery often looses the common Baltic implications and offers other arguments for self-identification.

The inherited patterns of Soviet mentality determine a similar structure of the characters' consciousness, identical personal values and motivational mechanisms that bear witness to a common stock type "Eastern European". This is a certain social type with the entire preconceived repertoire of stereotypical images describing the subject of post-Soviet descent. This subject appears in émigré narratives as the inferior figure of the labourer with low self-esteem, a person of no reputation guided by amorality and aggressiveness. Although, at first glance, all the personal and national characteristics of the homo post-sovieticus appear to be negatively charged, every unfavourable estimation contains the positive counterpart of the imageme that can be activated at any given moment (e. g., passivity/faithfulness, humility/patience, primitiveness/honesty, etc.).

Baltic literary works produced in more remote and exotic countries (China, Turkey and Georgia), reveal the Baltic identity as European (more specifically - Northern) as opposed to Russian or the Soviet one, and demonstrate
\end{abstract}

The article has been prepared in the framework of the Postdoctoral fellowship funded by European Union Structural Funds project "Postdoctoral Fellowship Implementation in Lithuania".

DOI: http://dx.doi.org/10.12697/IL.2015.20.1.13 
The Imagological Approach to Lithuanian and Latvian Contemporary Émigré Narratives

the authors' propensity for embracing it. Common representational clichés of a distant culture as the incomprehensible and foreign Other and of the Orient as the cradle of despotism are being disproved.

The images under discussion reflect Lithuanian and Latvian collective representations and the key changes happening in the national identity of the Baltic nations in emigration.

Keywords: literary imagology, national identity, ethnic image, Eastern European, imageme, exoticism, Lithuanian émigré literature, Latvian émigré literature

\section{The methodological starting points}

Each nation needs symbolic configurations, which formulate the centre of the national identity, create conditions for self-identification and separate one's own nation from other nations. Traditional understanding of national identity requires both origin and territory, while according to ethnic nationalists genealogy is more important than territory (Smith 1999: 190). Recent discourses on nationalism explain national identity as something one can voluntarily choose (Leerssen 2007: 27) rather than inherited immanent substance. Latvian writer Laima Muktupāvela (b. 1962) also associates homeland with a state of mind rather than space: "The centre of the world, traditions and home are there, where I am. I create my own traditions and I am my own home."2 (Muktupāvela 2003: 293)

For the basic theoretical premise I chose imagology, "the literary study of national characterization" (Leersen 2007: 310), which is, as the Croatian comparatist Davor Dukić puts it, "dominantly European and the less assertive older sister of post-colonial studies” (Dukić 2012: 15). As migrant identities are usually fluid and transformative, migration seems to be a continual threat to the self-image. On the other hand, émigré literature is very handy for studying selfimages as you can discover yourself better through the relation with the different and foreign Other.

The aim of this article is to discuss the potential of national and ethnic images captured in the $21^{\text {st }}$ century émigré narratives (novels, essays, diaries, travel notes and plays) and to grasp the new multiple identity of the Baltic nations, which develops when individuals leave their homeland for better material conditions or marital, cultural, academic, tourism-related, etc. circumstances. ${ }^{3}$

Unless otherwise indicated translations are my own.

3 In the span of the last two decades, Lithuania, a country with the population of 3.5 million, has lost more than half a million people - and that is just according to official 
Emigration as the massively spread myth of alleged success is also attributable to the field of contemporary imagology - legends about an ideal job, a stunningly successful career and easy money abroad, imposed by the media, stimulate the heroic image of the emigrant. A completely opposite myth of an emigrant as an apostate and anti-hero is not as popular and usually appears in speeches of specialists of demography, sociologists, economists or promoters of national ideals. Post-Soviet imaginations typically associate the freedom of the West with the image of abundance - the West is understood as the Mecca of material wealth and unlimited self-expression, which at the same time create a promise of symbolic power.

Referring to above-mentioned premises and employing the concepts of selfimage, imageme and counter-image introduced by contemporary literary imagology (Joep Leerssen), the article will trace some specific imagistic structures and identification patterns in contemporary Lithuanian and Latvian émigré fiction.

\section{Restructured tradition and flexible identity}

National myths are an important part of national ethnic symbols and particularly significant during periods of radical change (occupations, wars, fights for liberation), when national communities reconstruct their identity and look for new identification patterns. Emigration is a similar "shock experience" (Satkauskyte 2012: 32), which shakes the foundations of the self. Even before the European borders opened and before the Baltic emigration reached such a large scale as today, it was already possible to feel the trends of identity devaluation. Literary critics started to predict the depreciation of national values and archetypes: "Nationality is being deconstructed as a $19^{\text {th }}$-century relic, a symbolic projection of collectivism without a real social basis. The Homeland as a source of values, literary standards of Lithuanian culture and sacralised agrarian background, which was a vital source for Lithuanian identity during the years when the nation was deprived of its rights, tend to be sarcastically mocked" (Kubilius 2002: 69).

The works of current Lithuanian and Latvian émigré writers reflect these intensified processes as well. They invoke myths, manipulate traditional folkloric and mythological forms of expression and adjust them to their needs. Archaic Baltic beliefs lose their primary importance and the historical paradigm

figures. Latvian population has also shrunk by 13 per cent in little more than a decade. Our emigrational flows exceed the world's average 5-6 times. Lithuanians are emigrational champions in the European Union - journalists refer to it as "The great evacuation of Lithuania” (Lavaste 2012: 89). 
The Imagological Approach to Lithuanian and Latvian Contemporary Émigré Narratives

of nationality gradually gets forgotten. Language is no longer regarded as a symbolic backbone of the national identity. Gabija Grušaite (b. 1987) does not feel the mythical-historical Lithuanian nostalgia, she does not raise the issue of the national roots and declares the position of the "citizen of the world". Rugile, the character of Grušaitë's novel Neišsipildymas (Unfulfilment, 2010), constantly postulates that there is no identity - neither geographical (she constantly roams around Europe), nor sexual (she maintains a relationship with a person of the same sex), nor national (she does not feel any connection with her homeland). Grušaitè offers a typical image of the new émigré identity. Lithuanianness or Latvianness remains an inborn national belonging, but no longer a part of the self-image or self-perception. They are just automatic "carriers" of this nationality. However, the name Rugile does "localize" her in the cultural tradition - the root of the name Rugile ("rug-") is semantically significant and ethnically connoted, because it encodes the meanings of winter crops (rugiai) and rye bread (rugine duona), local and fundamental to the Baltic lands.

A social research conducted in Lithuania ten years ago revealed the major signs of the loss of national identity: forgetting one's mother tongue and native customs, building a mixed family, profession of a non-Christian religion, longing for the Soviet Union (Kuznecovienè 2008: 90). The body of émigré texts also suggests that the emigrants lose their social definition; the homeland is referred to as a country of smuggled cigarettes, cheap vodka and tasty beer instead of remaining the core of national identity. "Homeland with the capital H" (Fomina 2011: 310) is no longer the base for identity, a new slogan of the economical (e) migrants goes: "Home is where you hang your hat". This pragmatic aspect is encoded in the blue and red font of the Lithuanian chain supermarket Maxima used for Andra Manfelde's novel Dzimtenite (My Dear Homeland, 2012) cover design. It is an obvious reference to the atrophy of the ethnic and national imagination and the prevalence of a new type of materialistic imagery. Dzimtenite also means "moonshine" - home brew vodka; it is noteworthy but perhaps not unexpected that the existence of emigration is fully permeated with alcohol. Latvia - a sea state - has degenerated to the level that Latvian women clean and pack fish caught by foreign fishermen at Irish factories. The cosmogony of water as the source of life (the fish is one of the symbols of life in the Baltic folklore, while the boat symbolises the "womb of the great Mother or a cradle" (Celms 2010: 160) turns into the matrix of the world of death - the "fish morgue" (Manfelde 2012: 20)).

Religious and linguistic identities are no longer obligatory for the emigrant's personal identification. The Christian religion, formerly considered the factor consolidating the nation and an important part of its identity, no longer serves as a reliable pillar of ethnic identification. Emigration faces confessional 
"un-identification" - marrying a Muslim, women have to accept their faith, while the religion confessed by the Lithuanian emigrants, described by the Latvian writer Vilis Lācitis (b. 1975), is not Catholicism, since they belong to a fanatic religious sect. In Emigrantès dienoraštis (The Diary of an Immigrant, 2011) by Zita Čepaitè (b. 1957) Lithuanians are shown to be so ashamed of their Lithuanian language that even being among Lithuanians they pointedly talk only in English (Čepaitè 2011: 130). Paulina Pukytè (b. 1966) dedicates her entire book Bedalis ir labdarys (A Loser and a Do-gooder, 2013) to the radical nonsense of linguistic and cultural miscommunication. While sometimes Baltic people renounce their nationality completely, Lithuanians would rather choose to be French (Anra 2008: 94), Jewish (Čepaitė 2011: 129) or Estonian (Čepaitė 2011: 155). Writers emphasize the massive scale of emigration, transferring the earlier religious contents into arenas of consumer society. The new sanctuary of an emigrant is the airport:

Twenty years ago we joined hands on the Baltic Way. Today a living chain of emigrants, waiting at the gates of cheap airlines is three times longer than our legendary Baltic Way, stretching through England to the shores of Ireland. This is the longest living chain of emigration in the history of our nation. I am only a single link in it. (Davaine 2010: 115)

The Baltic Way is traditionally interpreted as a sacral historical point of reference, revealing the national, political and cultural identity of the three Baltic States. The symbolic act of the Baltic Way, reinterpreted by Elvyra Davaine in Airija: Tolima artima sala (Ireland: A Close Distant Land, 2010), is degraded from the ritual of national unity to a shapeless crowd of emigrants, milling around in transit spaces and departure halls. The airport, conceptualised by the anthropologist Marc Augé as a non-place (Augé 1995: 78), acquires a new social status in the reality of emigration - it becomes the key location of an emigrant, the new ritualistic space, even performing the role of a contemporary multireligious sanctuary:

All airports in the entire world are the same, all of them require you to kneel before the altar of registration and humbly wait for the invisible hands to return your luggage. I used to watch Christians, the godless, the Sikh and the Jewish kneeling before the same god and although he does not have a name, we at least know that he is real, tangible like Žilvinas, arising from a wave of oil and blood. (Grušaitè 2010: 23) 
The Imagological Approach to Lithuanian and Latvian Contemporary Émigré Narratives

Žilvinas is a reference to Lithuanian folklore and mythical world-view - Žilvinas and Eglè are the characters of the fundamental Lithuanian folk tale Egle žalčiu karaliene (Egle the Queen of Serpents). The mythologist Gintaras Beresnevičius believed this architext to be a possible equivalent of the Lithuanian theogonic myth (Beresnevičius 2003). Originally, Egle was calling her husband: "If alivemay the sea foam milk / If dead - may the sea foam blood", but the context of the technological consumer society completely transforms the semantics of this myth and the wave foams oil instead of milk. The imagery of this fairy tale is also employed in Išvarymas: Vieno obuolio kronika (Expulsion: the Chronicle of One Apple, 2012), the play by the Lithuanian author Marius Ivaškevičius (b. 1973). The ethnic identity of Eglè, a young Lithuanian woman who emigrates to London, is destroyed by a Briton, who pays her bills and calls her Ugly, because it is too difficult for him to pronounce her Lithuanian name. Egle literally means "a fir" and the evergreen fir is one of the trees that are very important for Lithuanian national self-consciousness. This new etymological invasion deconstructs the mythological and folklore-related consciousness, poses a threat to the integrity of the Lithuanian identity and undermines human self-esteem in general. The Lithuanian woman (traditionally Lithuanian women are regarded as beautiful) becomes "ugly", with all the implications of that word. The fairy tale Egle the Queen of Serpents also depicts a person's transformation (at first a serpent transforms into a human being and later humans are irreversibly turned into trees), while the new reality maintains the semantics of transformation and adapts the plot of the fairy tale depicting an irreversible transformation of an emigrant into a second-class being. Thus, the deconstruction of the name Egle in the context of the archaic Lithuanian fairy tale could be interpreted as the key turning point in the Baltic emigrant mentality and a transfer into the new level of anti-ethnicity and second-class identity. The projection of the name of Egle through the mythological memory results in the depreciation of the traditional myth and the creation of a new one.

\section{Eastern European as a dimension of Baltic identity}

Some of the modern emigrants were born and lived in the Soviet era, while the younger generation received their mental heritage via the indirect impact, thus a number of the examined literary representations raise the issue of the Baltic émigrée as a post-Soviet character. The Lithuanian critic Leonidas Donskis has introduced an effective principle of imagology into the context of the Lithuanian power and identity which is characterised by a distorted understanding of authority and dry-rot value orientations: "Lithuanian imagology cannot be 
imagined without what I call the culture of Soviet and post-Soviet cynicism. This culture immediately rejects all ideals and values as fictions. That is an immortal heritage of Marxism, a long-lasting 'gift' to the post-modern and postcommunist world.” (Donskis 2004: 86) Manipulations, deformed mentality and fabricated truth, all coming from the Soviet practice, are typical elements of the public discourse in Lithuania and Latvia, also reappearing in emigration and émigré fiction.

Social groups from Eastern Europe in emigration are united by common experiences and shared stereotypes; they feel affinity to each other in terms of interests and social hierarchy. Post-Soviet citizens are not burdened by any values: the brakes of decency or conscience, moral criteria or codes of honour. Intoxication with alcohol, drugs (and often their production too), scrimmage, smuggling, murder and prison are the typical topics of émigré literature, found in most of the literary works (Davainè 2010, Čepaitè 2013, Lācītis 2010, Fomina 2011, Pukytè 2013 etc.) with several insignificant exceptions.

In Leerssen's words, reading contemporary émigré literature, we "enjoy the power of literature to 'typify' certain 'characters"' (Leerssen 2007: 285). Here we encounter the stock type "Eastern European", which, like other concentric moral types distinguished by Leerssen, e.g. "the boastful old soldier", "the vain young dandy" or "the dumb blonde", include a certain repertoire of template meanings.

Londono vejas (The Wind of London, 2013), the novel by Lithuanian emigrant residing in London Zita Čepaitè, exhibits the imagery of an Eastern European and reveals that post-Soviet mentality and behavioural motivations, habits, skills and ways of action that move to London together with Lithuanian (e)migrants. The images of Soviet times and the beginning of the revival are often recalled by the protagonist Goda who embodies the negative characteristics of modern Lithuanians: immoral, aggressive and deceptive. The most valuable layer in the novel is the exposed roots of illegal business and the lessons of dirty profit of the homo postsovieticus, acquired at home and transferred to Great Britain. Former leaders of the Communist Youth, children of the high caste of the Soviet society (nomenklatura) who are trafficking arms, metal, currency and icons, still follow habits learned in those days when they run their businesses in the capitals of the world today.

The Eastern European identity revealed in the novels is based not only on the common collective memory and similar historical experiences, but on linguistics too. Aleksandra Fomina's (b. 1980) novel Mes vakar buvom saloje (Yesterday We Were on the Island, 2011) presents the Russian language as an important factor of social cohesion and identification, consolidating the sense of belonging - Üla, coming from the generation of "the last Soviet children" chats in Russian to her co-worker Tania from Ukraine and feels related to her 
The Imagological Approach to Lithuanian and Latvian Contemporary Émigré Narratives

with a special symbolic bond. Practitioners of imagology also admit that individuals and their groups, united by language or common social memory, can be regarded as the Other only "in a certain degree" (Spiering 1992: 58). Common (post)-Soviet identity describes the characters that come from Eastern Europe to work at London construction sites in the Latvian novel Stroika ar skatu uz Londonu (Construction Site with a View of London, 2010) written by Vilis Lācìtis. They experience a much lower psychological barrier communicating with those who share the same experiences but there is a symbolic hierarchy and social gradation among the Eastern European emigrants too: the Romanians, Bulgarians, Ukrainians, Belorussians and other emigrants from the countries that have not yet acquired an equivalent status in the European Union respect the Balts because that can result in personal gain: "Lithuanians can sell you all kinds of documents, anything you may need." (Lācitis 2010: 14). On the other hand, such fame of illegal business does not look good to the Lithuanians either. Vilis Lācitis states that the "Balts are the leaders in the struggle for survival" (Lācìtis 2010: 86), because former ascension to the European Union and a more secure situation in the labour market has given them symbolic superiority over other countries of the Eastern Block.

Post-Soviet citizens, raised in the spirit of collective ownership, are characterised by unbridled understanding of voluntaristic freedom ("anything is allowed", "everything is ours"), therefore they feel able to encroach on private property. Writers describe an irresponsible vulgaris type of people who unscrupulously violate the norms of a civilized state and promote impunity: "I was born in Eastern Europe and the British order did not worry me at all." (Lācîtis 2010: 42)

Historians and sociologists believe that Lithuanians are historically inclined to take the role of the exploited and seek for a master and authority, i.e. to serve someone and depend on someone. During the times of serfdom there was a need for a master, a nobleman, who used to take care of everything, and during the Soviet era this need shifted to the need for a Centre. The fiction created in emigration often supports the assumption that Eastern Europeans share an inherent inferiority complex and serfdom ideology: emigrants from Eastern Europe do not evade slave-like working conditions, exploitation, they agree to work for lower wages than the locals, work overtime, on weekends and at night. Material incentive makes them grovel, pander and endure all humiliations: "as they were warned by friends, employers prefer positive vocabulary and prick up their ears after hearing a 'no'. "Yes, sir. As you wish, sir. I will become an idiot for a few minutes, if you like me to, after all you do prefer softheads to smart ones, don't you, sir?" (Fomina 2011: 180). 
LAURUŠAITE்

Vytautas Kavolis, a Lithuanian émigré sociologist summarized the nation's inherited fundamental constellations using the metaphorical hypothesis of a "protective shell" (Kavolis 1993: 326). This concept is two-sided - on the one hand it may refer to resistance, on the other - cowardliness, isolation and unwillingness to do anything independently. In terms of imagology, these would be imagemes - "the term used to describe an image in all its implicit, compounded polarities" (Leerssen 2007: 344). Such pairs of imagemes would consist of Eastern European cowardliness/trustworthiness; humility/patience, primitiveness/honesty etc. Positive character traits, developed by the Soviet era and constructively applied in emigration include ingenuity and ability to survive every possible situation: in case of starvation one can find a container with food waste, loss of money pushes one to work on the street, being evicted from one's apartment one would move to a squat or even a tent in the forest to live as an "eco-homeless" (Lācītis 2010). Other traits, useful in emigration and attributable to the type of character raised in the Soviet times, are endurance and patience: "compared to these softies [the British - L.L.], Lithuanians are resistant like rock and patient like God himself" (Fomina 2011: 191). Living in unfavourable conditions for decades and longing for freedom to act and express themselves, Eastern Europeans became tough and developed controversial and even opposite characteristics, which help to guarantee their survival in a similarly inhospitable environment of emigration.

\section{Exotic "otherness" as a means of rethinking domestic identity}

When talking about the Baltic emigration to more distant countries (China, Turkey, Georgia), exoticism becomes an important extension of nationality. This chapter discusses the Baltic experience of confronting the exotic, which is either a true challenge for one's own identity or an incentive to nurture and foster it further. Having encountered exotic and remote cultures, Lithuanians and Latvians have to face their own ethnicity, while the background of the Other highlights the positive and negative sides of their mental silhouette and their Eurocentric identity. People from remote cultures usually identify the Balts with Europe as a wider ethno-geographical category, rather than with specific Baltic characteristics or with the Soviet and Russian heritage.

Many post-war émigré writers used to attack the exotic or at least distance themselves from it, while recent narratives demonstrate a certain wish to understand and embrace the difference. Lithuanian and Latvian authors in contemporary emigration try to turn away from the role of a stranger and establish a symbiotic relationship with their countries of residence and exotic 
The Imagological Approach to Lithuanian and Latvian Contemporary Émigré Narratives

locale $e^{4}$ : they are not judging the foreign and unknown cultures by the domestic (Baltic) logic, but try to "access them from inside" as the Latvian author Nora Ikstena puts it (Ikstena 2013: 71). This leads to a partial correction of the circulating images of Turkey, China and Georgia, to a fairer assessment and a revision of the stereotypical images. Baltic writers tend to overthrow and subvert the existing prejudices by questioning well-established clichés, both their own and foreign; thus stereotypes are intentionally invoked and reconstructed.

Audronė Urbonaitë's (b. 1954) novel Cukruota žuvis (The Sugar Coated Fish) offers a broader vision of identity.it as she calls it, and exposes the unreasoned Lithuanian fear of anything foreign. The gastronomic oxymoron of the Chinese dessert - sugar coated fish - personalizes Lithuania caramelized in stereotypes and wrapped in the sugary myth of the "true-born pure-blooded Lithuanian". A perspective of the Chinese, who in Urbonaitë's mind are going to overtake Baltic countries in just a few decades, helps to identify the provincial, xenophobic and self-centred thinking of Lithuanians and their self-aggrandizement. The essay collection Mana turku kafija (My Turkish Coffee) by Latvian author Laima Kota (previously Laima Muktupāvela, b. 1962) exposes the Baltic intolerance of Muslims, depicting Latvians who are visiting Turkey and are guided by prejudices against Turkish women as quiet, reserved, oppressed and treat them like victims of Turkish patriarchy; therefore, they can hardly comprehend and accept Laima's choice to marry a Turk. Kota deconstructs such an image, based on European stereotypes and - to use the leading imagologist Joep Leerssen's term - offers a positive counter image (Leerssen 2007: 343) of Turkey, claiming that she "could only wish Latvians lived as they live in Turkey" (Kota, 2012: 122). The Latvian writer Nora Ikstena (b. 1969) also steadily expresses her affection for Georgia and, in turn, stresses the Georgians' positive attitude to Latvians, going so far as to claim that the best wife for a Georgian is Latvian. She stresses an inborn gift of Georgians to be joyful and celebrate life on any given occasion: "Rhythm, sense of music, absolute air, joy of playing, singing and dancing are natural to Georgians" (Ikstena 2013: 98). The example of Georgians who set a table on the ruins after an earthquake and celebrated that they stayed alive becomes a telling illustration of their inner joyfulness and inherent resilience. Ikstena contrasts the Latvian "death program" and Georgian "life program” (Ikstena 2013: 100). Lithuanian and Latvian authors put Baltic gloominess against the cheerfulness of the Southern countries, and the Baltic peasant heritage against

4 Of course, the notion of "exotic" is rather relative here, because Turkey and China are more remote and bizarre in terms of cultural, racial and religious "otherness" than Georgia, which experienced the same Soviet past as did the Baltic States and is located geographically and mentally closer to the European centre. 
the noble Southern history: "They have the Sun in their [Chinese - L. L.] genes while we have some existential molecules." (Grainyte 2012: 119), "The Silk road is winding in Chinese genes, but the trail of the country wagon in ours" (Urbonaite 2012: 115). These contrasting characteristics imply that Baltic people are preconditioned to feel gloomy and unhappy; it is imprinted and stored in the nation's genetic memory and is partly determined by the cold, dark and rainy climate. Lithuania is often likened to a land of rain, wet and nasty weather (according to a widespread etymology, the name Lietuva - Lithuania originated from a Lithuanian word lyti - to rain). These climatic conditions are at the root of the melancholic and depressed Lithuanian character and its general passiveness: "Lithuania is a stagnated Baltic swamp" (Urbonaite 2012: 115) and "we lack colours, enthusiasm and vitality" (Urbonaite 2012: 31).

Baltic writers suggest that it is the Northern ethos and temperament that best typifies the Baltic national character. If Balts are usually seen as reserved and self-contained, all three Southern countries are depicted as centres of mass gatherings and collective celebration, embodying the mentality of the crowd as opposed to individualistic European thought, elevation of the self, need for privacy, silence and personal space. In the presence of the overwhelming sensual attack of the Southern flow of colours, sounds, and bustle in the Southern streets and oriental markets, Baltic people realize the smallness of their countries, and reconsider their homelands as just tiny dots on the world's map: "I've learned a lesson that Lithuanian scales are not valid in this country and I have to forget the term 'town' while I am here, in China” (Grainyte 2012: 47), "Turkey taught me to see myself not as a beginning of the world, but as an organic part of it" (Kota 2012: 157).

Lithuanian and Latvian authors do not dwell on the troubles of being foreign, but rather use the opposite perspective to reflect on their alterity which Ikstena calls "particularity and depth of foreigner's sight" (Ikstena 2013: 9). None of the authors adopt the stereotypical negative image of the exotic countries. They do not stress the superiority of European (or ethnic Baltic) culture and provide cultural references that transcend and even subvert the stereotypical division into the images of the foreign as inferior and those of the self as more advanced and superior. On the contrary, Baltic writers tend to idealize the exotic Other and expose the limitations of their Baltic provincialism. As Leerssen has argued, "This positive appreciation of the exotic is in some respects the very opposite to ethnocentrism: the foreign country is positively valorised and in many cases seen as a preferable alternative to one's domestic country" (Leerssen 2007: 325). 
The Imagological Approach to Lithuanian and Latvian Contemporary Émigré Narratives

Conclusions or the final points on the issue

Changing character reputations, conveyed in the texts of the new-wave (e)migration, are an important factor in order to understand the specifics of our (e) migrational imagery. The typology of recurring images (the airport as the new sanctuary, changed forms of the folk tale Egle the Queen of Serpents, the pragmatic interpretation of the homeland, etc.) shows their imagotypical nature (Spiering 1992: 17). Lithuanians and Latvians blend into the network of European and global identities, start thinking more universally and are increasingly likely to go beyond the boundaries of ethnicity. Most of the characters in Lithuanian and Latvian novels could be regarded as transmigrants. What describes them best is neither living between two cultural traditions nor fragmentation, but rather the nomadic lifestyle, which entwines traditions and erases cultural boundaries. A possibility to belong nowhere is understood as a privileged condition, while ethnicity, on the other hand, as limiting and claustrophobic. However, it could be said that national, regional images and their modifications are still important in order to understand the expressive mechanism of the contemporary (e)migratory identity, even in such cases, when they are criticized, transformed or denied, because the symbolic foundation of the new identity can be described only by contrast with the old one. Those Baltic writers who emigrated to exotic countries do not reject or deny their ethnicity, but try to bring it out and grasp it. Exoticism becomes a desirable extension of one's own nationality and the way to feel your own exclusivity.

The literary works are full of direct and indirect references to the common experience of the post-communist block, which allows discussing the collective (post)-communist status as the basis of identity. A similar structure of consciousness and motivational mechanisms allow identifying the common Eastern European stock type. During fifty years of occupation an individual consciousness was heavily indoctrinated and the deeply rooted post-communist heritage is resistant and durable. It manifests not only externally as skills or habits, but also on the internal plane of the world-view, morality and behavioural motivation.

\author{
Laura Laurušaitè \\ laura@llti.lt \\ Lietuvos edukologijos universitetas \\ T. Ševčenkos g. 31 \\ LT-03111 Vilnius \\ LIETUVA
}


LAURUŠAITE்

\section{Bibliography}

Anra, A. 2008. Katinas Temzèje. Vilnius: Versus aureus.

Augé, M. 1995. Non-places: Introduction to the Anthropology of Supermodernity. LondonNew York: Verso.

Beresnevičius, G. 2003. Eglè žalčių karalienè ir lietuvių teogoninis mitas. Vilnius: Kultūros, filosofijos ir meno institutas.

Celms, V. 2010. Baltų raštai ir ženklai: Baltų pasaulio modelis. Struktūra. Vaizdiniai. Simboliai. Vilnius: Mintis.

Čepaitè, Z. 2011. Emigrantès dienoraštis. Vilnius: Alma littera.

Čepaitè, Z. 2013. Londono véjas. Vilnius: Alma littera.

Davainè, E. 2010. Airija: Tolima artima sala. Vilnius: Baltos lankos.

Donskis, L. 2004. Pilietinè visuomene ir jos priešai: Autoritetas, tiesa ir viešoji erdvė XXI amžiaus Lietuvoje. Vilnius: Versus aureus.

Dukić D. 2012. Foreword. - D. Dukić, ed., Imagology Today: Achievements, Challenges, Perspectives, Germany: Bouvier Verlag, 11-16.

Fomina, A. 2011. Mes vakar buvom saloje. Vilnius: Kitos knygos.

Grainytė, V. 2012. Pekino dienoraščiai. Vilnius: Vaga.

Grušaitè, G. 2010. Neišsipildymas. Vilnius: Baltos lankos.

Ikstena, N. 2013. Dievmātes draudzene. Rīga: Dienas grāmata.

Ivaškevičius, M. 2012. Išvarymas: Vieno obuolio kronika. Vilnius: Apostrofa.

Kavolis, V. 1993. Lietuviai, komunizmas ir tautinis charakteris. - V. Gasiliūnas, ed., Metmenu laisvieji svarstymai. Vilnius: Vaga, 314-328.

Kota, L. 2012. Mana turku kafija. Rīga: Dienas grāmata.

Kubilius, V. 2002. Kultūra globalizacijos glèbyje. - Lietuvių tauta ir pasaulis. Kaunas: Gabija, 65-71.

Kuznecovienė, J. 2008. (Ne)lietuviškumo dėmenys: savo/ svetimo ribų braižymas. V. Čiubrinskas, J. Kuznecovienė, eds., Lietuviškojo identiteto trajektorijos. Kaunas: Vytauto Didžiojo universitetas, 89-108.

Lācītis, V. 2010. Stroika ar skatu uz Londonu. Rīga: Mansards.

Lavaste, L. 2012. Mes. Lietuviai. Vadovèlis, kaip suprasti lietuvius ir jais naudotis. Vilnius: Tyto alba.

Leerssen, J. 2007. Character (moral). - J. Leerssen, M. Beller, eds., Imagology: The Cultural Construction and Literary Representation of National Characters. A Critical Survey. Studia Imagologica 13. Amsterdam-New York: Rodopi, 284-287.

Leerssen, J. 2007. Image. - J. Leerssen, M. Beller, eds., Imagology: The Cultural Construction and Literary Representation of National Characters. A Critical Survey, Studia Imagologica 13. Amsterdam-New York: Rodopi, 342-344.

Leerssen, J. 2007. Imagology: History and Method. - J. Leerssen, M. Beller, eds., Imagology: The Cultural Construction and Literary Representation of National Characters. A Critical Survey. Studia Imagologica 13. Amsterdam-New York: Rodopi, 17-32.

Manfelde, A. 2012. Dzimtenite. Riga: Literatūras kombains.

Muktupāvela, L. 2003. Pievagrybių testamentas: Juodieji baltai pas keltus. Vilnius: Mintis. Pukytè, P. 2013. Bedalis ir labdarys. Vilnius: Apostrofa. 
The Imagological Approach to Lithuanian and Latvian Contemporary Émigré Narratives

Satkauskytė D. 2012. „Lètas transkultūrinis tapsmas” ir jo vertès naujausioje lietuvių emigrantų literatūroje. - Žmogus ir žodis, II, 31-38.

Smith, A. D. 1999. Myths and Memories of the Nation. Oxford: Oxford University Press. Spiering, M. 1992. Englishness: Foreigners and Images of National Identity in Postwar Literature. Studia Imagologica 5. Amsterdam-Atlanta: Rodopi.

Urbonaitè, A. 2012. Cukruota žuvis. Vilnius: Alma littera. 